\title{
EXECUTION OF THE CONFEDERATE SPY SAMUEL DAVIS.
}

\author{
BY MAJ, GEN. G. M. DODGE.
}

(From the Confederate Veteran.)

When Gen. Grant ordered Gen. Sherman (whose head of column was near Eastport, on Tennessee river) to drop everything and bring his army to Chattanooga, my corps (the 16th) was then located at Corinth, Miss., and I brought up the rear.

Gen. Grant's anxiety to attack Bragg's command before Longstreet could return from East Tennessee brought on the battle before I could reach Chattanooga. Gen. Grant, therefore, instructed Gen. Sherman to halt my command in Middle Tennessee and to instruct me to rebuild the railway from Nashville to Decatur. The fulfilling of the above order is fully set forth by Gen. Grant in his Memoirs.

When I reached the line of the Nashville and Decatur railroad, I distributed my troops from Columbia south towards Athens, Alabama. I had about 10,000 men and 8,000 animals and was without provisions, with no railroad or water communication to any base of supply, and was obliged to draw subsistence for my command from the adjacent country until I could rebuild the railroad and receive my supplies from Nashville.

My command was a part of the "Army of the Tennessee," occupying temporarily a portion of the territory of the "Department of the Cumberland," but not reporting or subject to the commander of that department.

Upon an examination of the country, I found that there was an abundance of everything needed to supply my command, except where Sherman's forces had swept across it along Elk river. He wrote me "I do not think that my forces have left a chicken for you." I also found that I was in a country where the sentiment of the people was almost unanimously against us. I had very little faith in convert- 


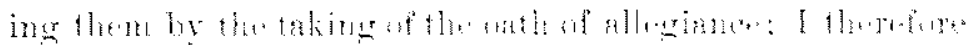

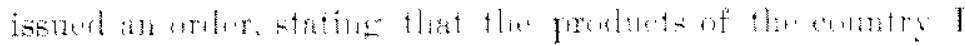

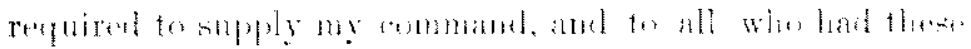

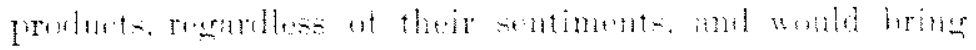

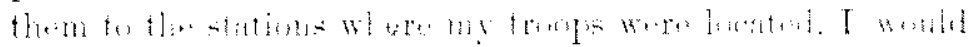

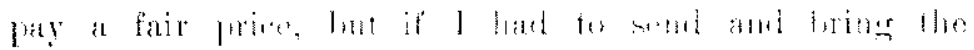

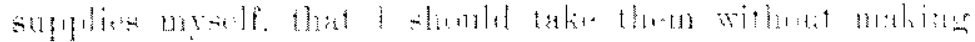

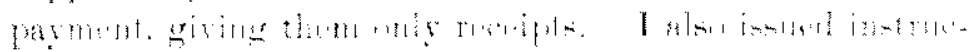

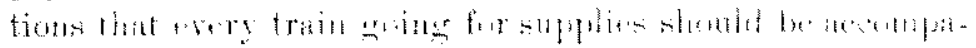

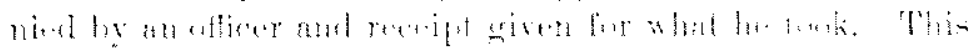

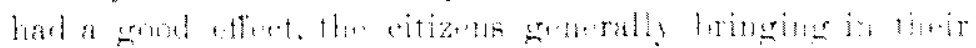

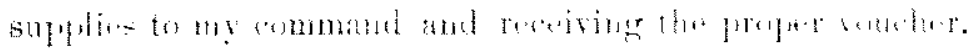

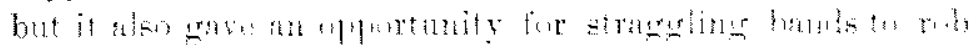

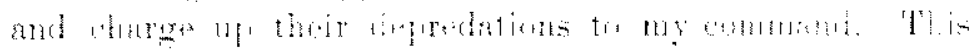

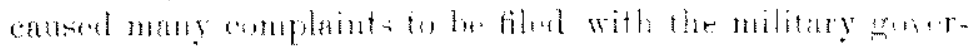

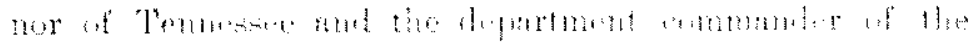
Comberlinil.

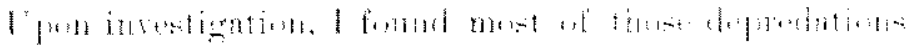

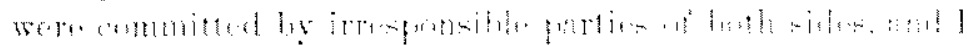

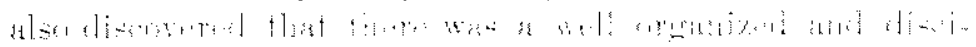

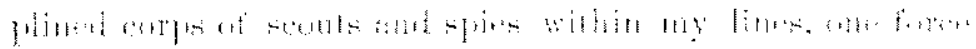

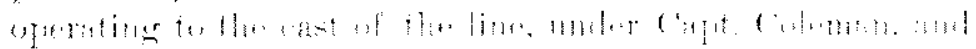

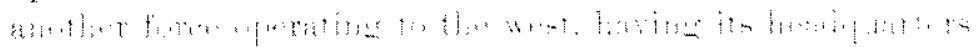

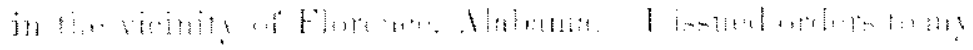

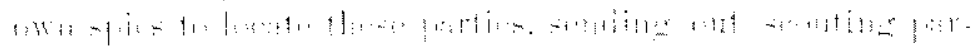

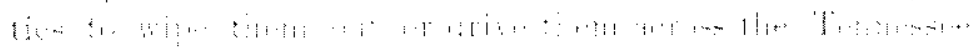
risis.

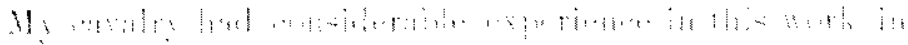

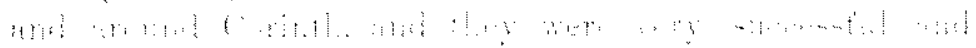

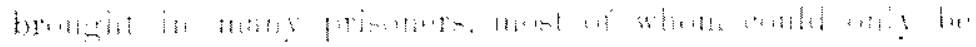

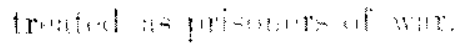

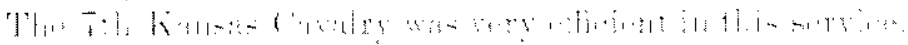

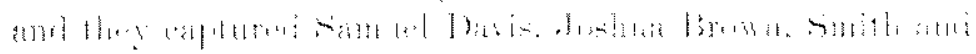

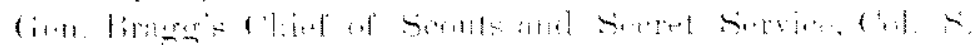

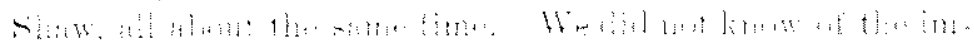

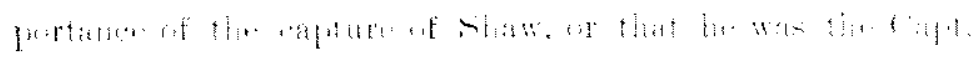




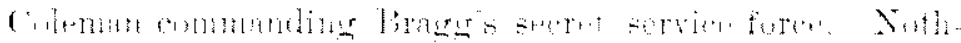

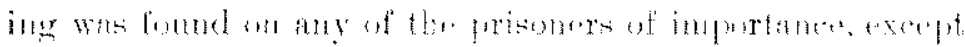

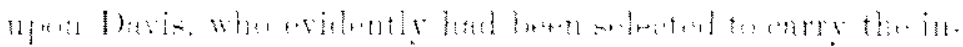

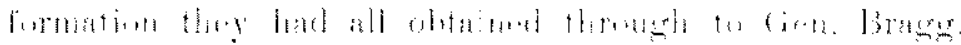

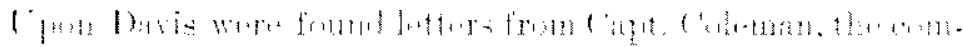

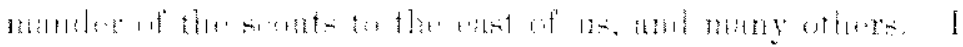

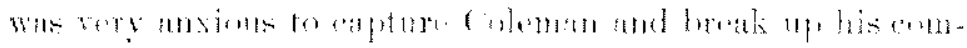

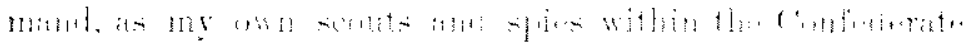

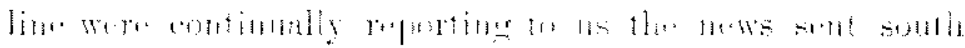

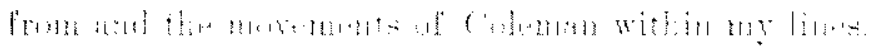

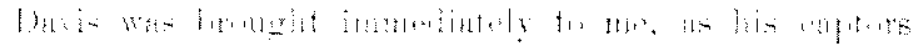

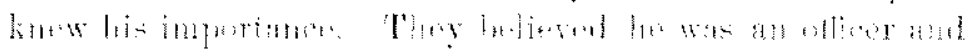

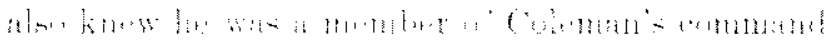

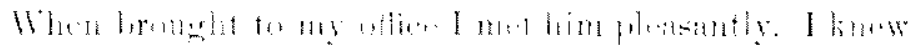

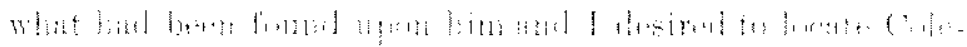

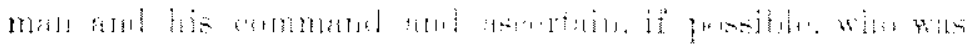

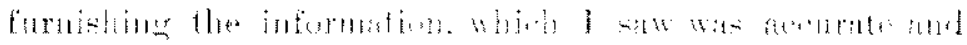

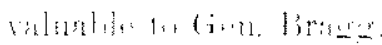

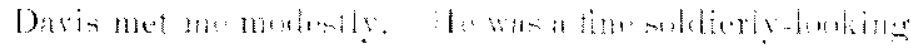

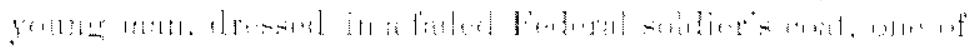

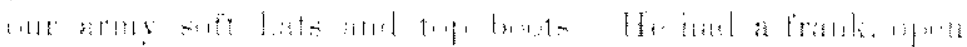

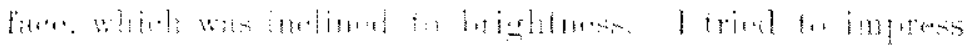

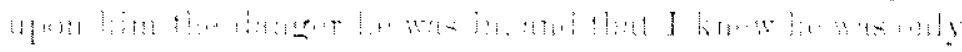

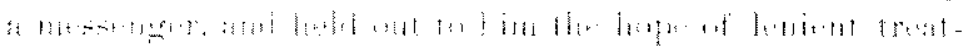

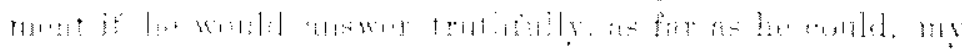
(jirintiand

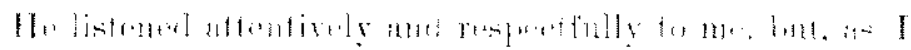

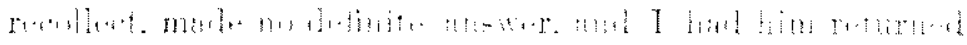

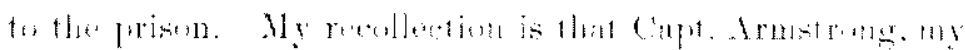

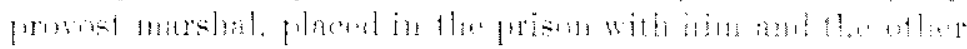

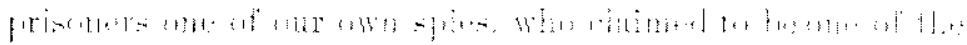

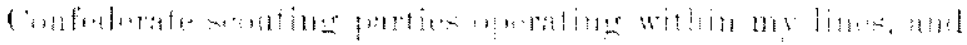

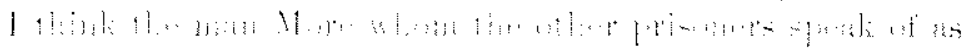

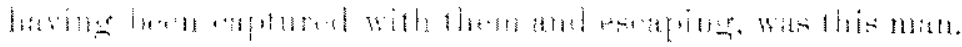

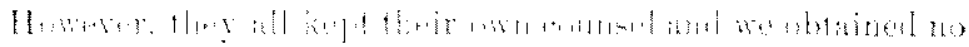

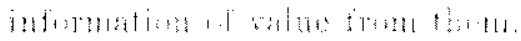


The reason of this reticence, was the fact that they all knew Col. Shaw was one of our captives, and that if his importance was made known to us he would certainly be hung, and they did not think that Davis would be executed.

Upon Davis was found a large mail of value. Much of it was letters from the friends and relatives of soldiers in the Confederate army. There were many small presents, one or two, I remember, to Gen. Bragg, and much accurate inform ation of my forces, of our defences, our intentions, substance of my orders, criticisms as to my treatment of the citizens and a general approval of my payment for supplies, while a few denounced severely some of the parties who had hauled in supplies under the orders.

Capt. Coleman mentioned this in one of his letters.

There were also intimations of the endeavor that would be made to interrupt my work, and plans for the capture of single soldiers and small parties of the command out after forage.

I had Davis brought before me again, after my provost. marshal had reported his inability to obtain anything of value from him. I then informed him that he would be tried as a spy; that the evidence against him would surely convict him, and made a direct appeal to him to give me the information I knew he had. He very quietly, but firmly, refused to do it. I therefore let him be tried and suffer the consequences. Considerable interest was taken in young Davis by the provost marshal and Chaplain Young, and considerable pressure was brought to bear upon them by some of the citizens of Pulaski; and I am under the impression that some of them saw Davis and endeavored to induce him to save himself, but they failed. Mrs. John A. Jackson, I remember, made a personal appeal in his behalf directly to me. Davis was convicted upon trial and sentenced. Then one of my noted scouts, known as "Chickasaw," believed he could prevail upon Davis to give. the information we asked.

He took him in hand and never gave it up until the last 
moment, going to the scaffold with a promise of pardon a few moments-before his execution.

Davis died to save his own chief, Col. Shaw, who was in prison with him and was captured the same day.

The parties who were prisoners with Davis have informed me that it was Shaw who had selected Davis as the messenger to Gen. Bragg, and had given him part of his mail and papers.

I did not know this certainly until a long time after the war. I first learned of it by rumor and by what some of my own scouts have told me since the war, and it has since been confirmed confidentially to me by one of the prisoners who was captured about the same time that Davis was and who was imprisoned with him up to the time he was convicted and sentenced, and knew Col. Shaw, as well as all the facts in the case.

The statement made to me was that Col. S. Shaw was the chief or an important officer in Gen. Bragg's secret service corps; that Shaw had furnished the important documents to Davis, and that their captors did not know Shaw and his importance.

Col. Shaw I sent with the other prisoners north, as prisoners of war. I also learned that Shaw was greatly alarmed when he was informed that I was trying to induce Davis to give me the information he had.

This is where Davis showed himself a true soldier. $\mathrm{He}$ had been entrusted with an important commission by an important officer, who was imprisoned with him, and he died rather than betray him. He knew to a certainty, if he informed me of the facts, that Shaw would be executed, for he was a far more important person to us than was Davis.

During the war I had many spies captured; some executed who were captured within the Confederate lines and who were equally brave in meeting their fate.

By an extraordinary effort I saved the life of one who was captured by Forrest. Through my efforts this man es. 
caped, though Gen. Forrest sized him up correctly. He was one of the most important men we ever had within the Confederate lines.

Forrest was determined to hang him, but Maj. Gen. Polk believed him innocent and desired to save him.

Great interest was taken in Davis at the time, because it was known by all of the command that I desired to save him.

Your publication bears many evidences of this fact. It is not, therefore, necessary for me to state that I regretted to see sentence executed; but it was one of the fates of war, which is cruelty itself, and there is no refining it.

I find this letter bearing upon the case; it may be of interest. It is my first report to Maj. B. M. Sawyer, assistant adjutant general, Army of the Tennessee, notifying him of the capture of Davis. It is dated Pulaski, Tenn., Nov, 20th, 1863, and is as follows:

I herewith enclose copy of dispatches taken from one of Bragg's spies. He had a heavy mail, papers, etc., and shows Capt. Coleman is pretty well posted.

We have broken up several bands of mounted robbers and Confederate cavalry in the last week, capturing some five commissioned officers and one hundred enlisted men, who have been forwarded.

I also forward a few of the most important letters found in the mail. The tooth brushes and blank books I was greatly in need of and therefore appropriated them. I am,

Very respectfully, your obedient servant, G. M. DODGE, Brigadier General.

The severe penalty of death, where a spy is captured, is not because there is anything dishonorable in the fact of the person being a spy, as only men of peculiar gifts for such service, men of courage and cool judgment and undoubted patriotism are selected. The fact that the information they obtain is found within their enemy's lines and probably of great danger to an army is what causes the penalty to be so very severe. A soldier caught in the uniform, or a part of the uniform of his enemy, within his enemy's lines, establishes the fact that he is a spy and is there in violation of the Articles of War and for no good purpose. This alone will prohibit his being treated as a prisoner of war, when caught as Davis was in our uniform, with valuable documents upon him, and seals his fate. 
I appreciate fully that the people of Tennessee and Davis' comrades understand his soldierly qualities and propose to honor his memory. I take pleasure in aiding in the raising of a monument to his memory, for although the services he performed were for the purpose of injuring my command, they were given in faithfully performing the duties he was assigned to.

New YoRK, June 15, 1897.

\section{THE REIGN OF THE COMMON PEOPLE.}

In the broadest sense, therefore, the common people rule, their joint action prevails, their harmonious wishes dominate education. There is no efficiency like their efficiency. There is no power like their power. There is no development like their development. They stand supreme to all those who serve their interests in any capacity. They love their accepted leaders, they admire their patriotic teachers, they ardently accept their highest conception of what is best. They are ready to grant their allegiance to the truth; they are strong in their admiration for genuine capability, while they hate all shams, sycophancy and trickery. Manliness has in such an environment an influence that cannot be measured in terms of speech, efficiency in service is recognized by the mightiest applause, while the spirit of honor and strength gives to civilization its greatest elevation. The time has come to learn this lesson in the management of public education of relying upon the common people. The great demand for the present is for a stronger affliation with the father and the mother of the boys and girls in the school room on the part of every would-be educator. The largest and most effective career is possible alone to those who know their allegiance to the principles of democracy and who intelligently apply these principles to the solving of the great problems that are daily found in the work.-President H. H. Seerley, State Normal School. 
Copyright of Annals of Iowa is the property of State of Iowa, by \& through the State Historical Society of Iowa and its content may not be copied or emailed to multiple sites or posted to a listserv without the copyright holder's express written permission. However, users may print, download, or email articles for individual use. 